\title{
INFLUENCE OF CHLORIDES AND SULPHATES ON QUALITY OF BIOLOGICAL WASTEWATER TREATMENT USING ENZYME PREPARATIONS
}

\author{
Audra Skaisgiriené ${ }^{1}$, PetrasVaitiekūnas ${ }^{2}$, Vytenis Zabukas ${ }^{3}$ \\ 1, 2Dept of Environmental Protection, Vilnius Gediminas Technical University, Saulètekio al. 11, \\ LT-10223Vilnius-40,Lithuania.E-mail: Iaudra.s@delfi.lt,2vaitiek@itpa.lt \\ ${ }^{3}$ Dept of Technological Processes, Klaipeda University, Bijūnu g. 17, LT-91225 Klaipeda, Lithuania \\ E-mail: ${ }^{3}$ dekanas@jtf.ku.lt
}

Received 28 Apr 2004; accepted 1 Jun 2004

\begin{abstract}
The biological treatment method is widely used in Lithuania due to its high efficiency, low cost and suitability for treating various types of wastewater. After technological processes various mineral substances, such as chlorides and sulphates, get into water bodies. These substances are not removed from wastewater by the biological treatment method. The purpose of this study is to determine the concentrations of chlorides and sulphates, investigate the influence of enzyme preparations upon quality and energy consumption and assess energy changes in the trophic food chain during biological treatment. To analyse the mineral salt influence of the biooxidation process a series of laboratory tests was carried out: biochemical oxygen consumption (BOD), activated sludge concentration and other indexes. It is found experimentally that a $400 \mathrm{mg} / \mathrm{l}$ concentration of chlorides disarranges the activity of microorganisms, and at a $700 \mathrm{mg} / \mathrm{l} \mathrm{concentra-}$ tion active sludge is no longer suitable for biological treatment. Also, we investigated the effect of a ferment preparation "Roebic" on effluence of sewage treatment. In a tank with an enzyme the total amount of energy after treatment increases by $5-30 \%$. It is determined by calculating the accumulation of energy in an active-sludge system that an enzyme preparation increases the energy levels of the system.
\end{abstract}

Keywords: activated sludge, enzymes, biological wastewater treatment, sulphates, chlorides

\section{Introduction}

The problems of the protection of water bodies are closely related to treatment of wastewater discharged to them, however, municipal wastewater treatment facilities in most towns of Lithuania cannot ensure the quality of treatment. The biological treatment method is widely used in Lithuania due to its high efficiency, low cost and suitability for treating various types of wastewater. Biochemical wastewater treatment processes are most easily regulated in active-sludge facilities. However, biochemical wastewater treatment processes are very complex and depend on a number of factors, including the chemical composition and concentration of organic matter in wastewater, water temperature and $\mathrm{pH}$, and the content of toxic substances in water [1].

It is noted that the concentrations of wastewater delivered to treatment facilities have increased lately. After technological processes various mineral substances, such as chlorides and sulphates, get into water bodies. These substances are not removed from wastewater by the biological treatment method. Chlorides get into wa- ter both with domestic and industrial wastewater because chlorine and chlorine compounds are used for rendering wastewater harmless [2]. Chlorine compounds are used to destroy pathogenic microorganisms, to remove odours in slaughterhouses and fish-processing enterprises, to salt foodstuffs in food industries, etc.

Microorganisms are sensitive to changes in osmotic pressure in the medium. Larger amounts of mineral salts $(\mathrm{KCl}, \mathrm{NaCl})$ evoke plasmolysis inside the cells of microorganisms as a result of which microorganisms are destroyed.

The efficiency of wastewater treatment depends upon a number of factors including catalysts. While enzymes facilitate metabolism, sulfates acidify the medium for microorganisms which has a negative effect upon enzyme activities.

The purpose of this study is to determine the concentrations of chlorides and sulphates, investigate the influence of an enzyme preparation upon quality and energy consumption and assess energy changes in the trophic food chain during biological treatment. 


\section{Investigation methods}

The amount of oxygen dissolved in water was determined by the Winkler's method [3]. The essence of the biochemical oxygen consumption $\left(\mathrm{BOD}_{5}\right)$ method $[4$, 5] consists in the analysis of a water sample after shaking it and keeping at $20{ }^{\circ} \mathrm{C}$ for five days in a dark place in filled and sealed bottles. The concentration of dissolved oxygen is measured before and after the incubation. Oxygen consumption per litre of a sample is calculated.

A model consisting of two tanks with a capacity of 5 litres each was used for the experiment. The working volume of each tank was 3 litres. Using air supplied by micro-compressors, active sludge is constantly mixed with water and maintained in a suspended state. The operating conditions selected were similar to those of an aeration tank of the operation period in which aeration and mixing of active sludge takes place 20 hours per day, then aeration is switched off for 4 hours leaving water to settle. During the adaptation period (3-4 days), the microorganisms in the sludge adapt to the medium. The substrate used for the adaptation stage and the experiment consisted of glucose $150 \mathrm{mg} / \mathrm{l}$ and yeast suspension $150 \mathrm{mg} / \mathrm{l}$ [6]. Additionally, the following pollutants were introduced: $\mathrm{KCl}$ (chloride concentration of $200 \mathrm{mg} / \mathrm{l}$ and $400 \mathrm{mg} / \mathrm{l}$ ), during another experiment $\mathrm{K}_{2} \mathrm{SO}_{4}$ (sulfate concentration of $300 \mathrm{mg} / \mathrm{l}$ and $700 \mathrm{mg} /$ 1). The enzyme preparation Roebic was added into the second tank $(1,2 \mathrm{ml} / \mathrm{l})$. After 20 hours aeration was switched off and samples taken upon settlement of active sludge [7]. The experimental model is schematically depicted in Fig 1.

To determine the accumulation of energy in the active sludge system, the theoretical calorific value of wastewater is calculated from the formula (1) [8]:

$$
\begin{gathered}
\mathrm{K}=2,326 \cdot\left[145 \cdot \mathrm{C}+610\left(\mathrm{H}_{2}-\right.\right. \\
\left.\left.-0,125 \cdot \mathrm{O}_{2}\right)+40 \cdot \mathrm{S}+10 \cdot \mathrm{N}\right], \mathrm{J} / \mathrm{kg}
\end{gathered}
$$

where $\mathrm{C}$ is the share of carbon in the organic matter $(\%$ by weight); $\mathrm{H}_{2}$ is the share of hydrogen in the organic matter ( $\%$ by weight); $\mathrm{O}_{2}$ is the share of oxygen in the organic matter (\% by weight); $\mathrm{S}$ is the share of sulphur

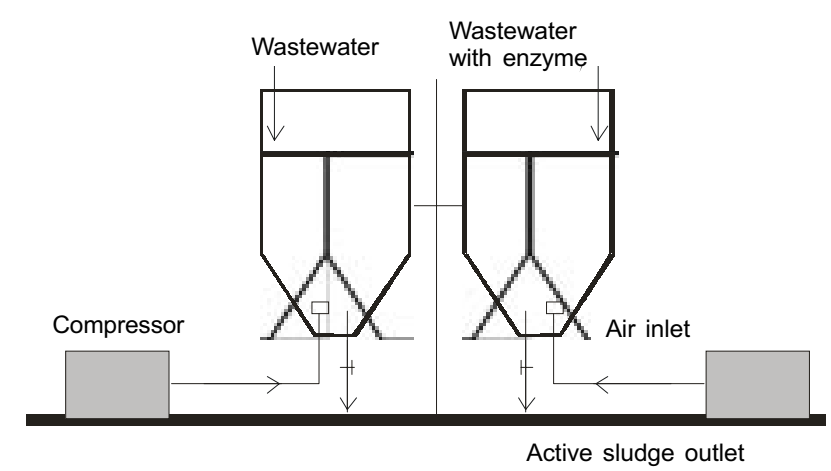

Fig 1. Schematic diagram of the experimental model in the organic matter ( $\%$ by weight); $\mathrm{N}$ is the share of nitrogen in organic matter ( $\%$ by weight).

\section{Experiment results}

The energy indispensable for maintaining vital functions (e g, metabolism - breathing or evaporation) is obtained by splitting highly energetic substances (dissimilation, catabolism).

The biological treatment of wastewater is based on the biochemical oxidation of substances. Biological oxidation is enzyme oxidation of cell substrates with the main final products being $\mathrm{CO}_{2}, \mathrm{H}_{2} \mathrm{O}$, and urea. It differs from oxidation taking place in inanimate nature in that 1) it is a gradual oxidation of substrates and the released energy is stored in macro energetic compounds and specific chemical bonds; 2) enzymes are its catalysts, and 3) energy is released as hydrogen is oxidized to produce water. The larger the number of nutritional links in the system, the higher the energy consumption.

The indicators, such as $\mathrm{BOD}_{5}$, sludge index and sludge concentration, were observed in the course of the experiment; indicator microorganisms were also observed through a microscope.

During the experiment with $\mathrm{KCl}, 230 \mathrm{BOD}_{5}, 60$ sludge indexes and 60 concentration samples were examined; $\mathrm{K}_{2} \mathrm{SO}_{4}-170 \mathrm{BOD}_{5}$ samples, 40 sludge indexes and 40 sludge concentration samples.

\subsection{Influence of chlorides upon biological wastewa- ter treatment}

Organic matter dissolved in water accounts for the largest part of pollutants. In the course of experiment with $\mathrm{KCl}$ the effect of chloride ions upon the biochemical oxidation processes and splitting of organic pollutants was studied. The influence of $\mathrm{KCl}$ over metabolism in the active sludge system was also determined. Three parallel investigations were conducted: 1) $\mathrm{KCl}$ without pollution, 2) $200 \mathrm{mg} / \mathrm{l} \mathrm{Cl}^{-}$, 3) $400 \mathrm{mg} / \mathrm{l} \mathrm{Cl}^{-}$. A daily concentration of $\mathrm{Cl}^{-}$that does an irreparable damage to active sludge was established. Where the concentration of chlorides in wastewater reaches $700 \mathrm{mg} / \mathrm{l}$, the micro-organisms of active sludge are destroyed and sludge flakes rise to the surface of water instead of settling after aeration is switched off. Such an active sludge is not suitable for the biological treatment of wastewater.

It is noted during the experiment that the higher chloride concentration in wastewater, the stronger a positive effect of enzymes. Fig 2 shows the dependence of biochemical oxygen demand upon the concentration of chlorides after biological treatment of wastewater. As the chloride concentration varies from 0 to $400 \mathrm{mg} / \mathrm{l}$, the dependence is described by a second-order parabola. As the concentration of chlorides was increased to $400 \mathrm{mg} / \mathrm{l}, \mathrm{BDS}_{5}$ remained stable throughout the experiment in the tank with an enzyme preparation. This is because the enzyme preparation used contained bacterial spores that enable continu- 


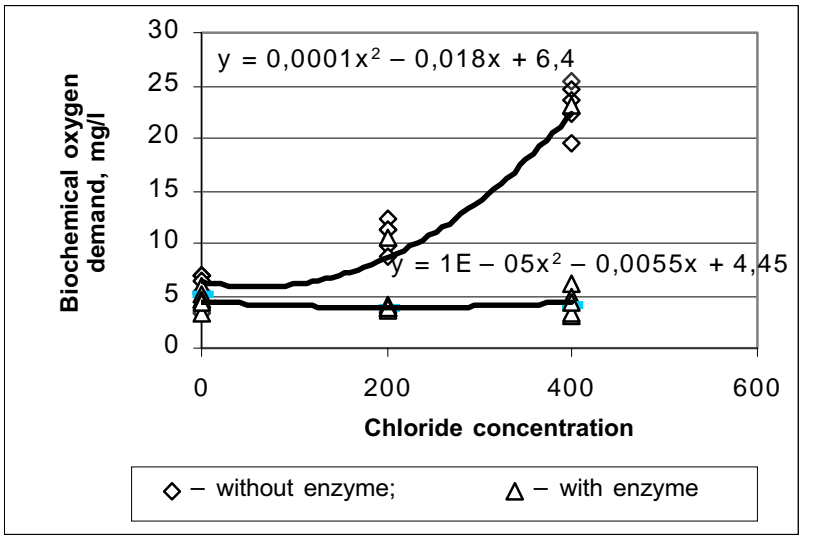

Fig 2. Dependence of biochemical oxygen demand upon chloride concentration

ous renewal of active sludge. The larger the amount of microorganisms, the higher the quality of wastewater treatment and the lower $\mathrm{BOD}_{5}$, after treatment. In the tank without an enzyme preparation the concentration of $\mathrm{BOD}_{5}$ increased with increase in chloride concentration and was higher by almost $20 \mathrm{mg} / \mathrm{l}$ than that in the tank with the preparation. Chlorides are characterized by an antiseptic effect. Where the concentration of $\mathrm{Cl}^{-}$in wastewater reaches $400 \mathrm{mg} / \mathrm{l}$, a large part of active sludge microorganisms, including microorganisms participating in the BOD process, are destroyed. This is shown in Fig 3.

While a high concentration of chlorides $(400 \mathrm{mg} / \mathrm{l})$ that get into the tank with wastewater reduced active sludge concentration more than twice (from 2,45 g/l to $1,05 \mathrm{~g} / \mathrm{l})$ in five days, the use of an enzyme preparation resulted in a very slight change in active sludge concentration (from $2,21 \mathrm{~g} / 1$ to $1,80 \mathrm{~g} / \mathrm{l}$ ).

Osmotic pressure increases with increase of chloride concentrations. Different concentration of solutions of the medium and the cell cytoplasm is the main driver of osmotic absorption of nutrients. The higher the concentration of chlorides in the medium, the larger the amount of water diffused from the cells to the medium;

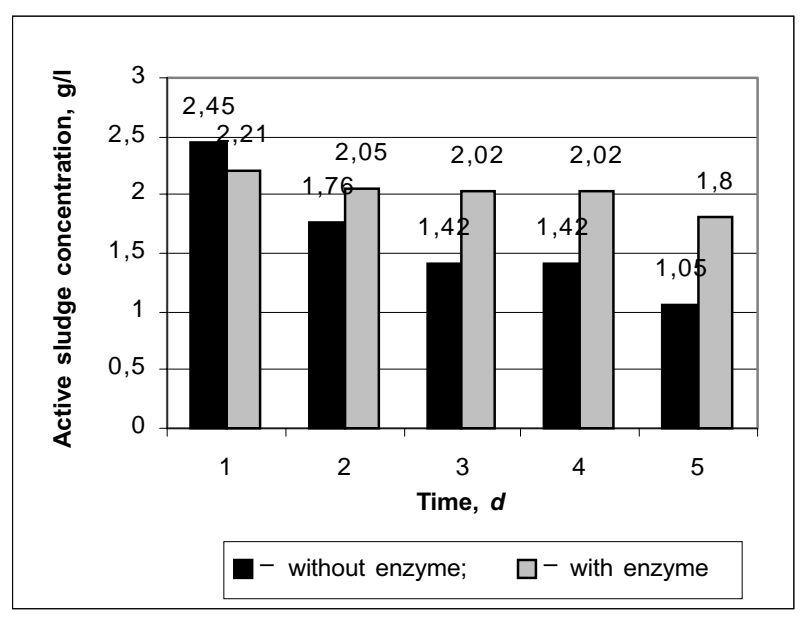

Fig 3. Dependence of active sludge concentration upon time (chloride concentration of $400 \mathrm{mg} / \mathrm{l}$ ) the cytoplasm shrinks, wrinkles and comes off the membrane and wall, as a result of which nutrients do not reach the cells. Cells are destroyed and the concentration of active sludge lowers.

The biochemical oxidation of organic matter is closely related to the metabolism in an active-sludge system, therefore, the accumulation of energy in active sludge was determined on the basis of the findings of the experiment. 1,8 litres of wastewater $(533,58 \mathrm{kcal})$ was added into the tank. The investigation shows that the energy value of $1 \mathrm{~kg}$ of dry active sludge was $15,000 \mathrm{~kJ}$ or $3585 \mathrm{kcal}$ which corresponds to the theoretical calculation results.

There is a direct dependence between the amount of energy in an active-sludge system and the amount of microorganisms. The total amount of energy before treatment is proportional to the concentration of active sludge in the tank because the baseline BOD is constant and equal to $192 \mathrm{mg} \mathrm{O} / 1$. The total amount of energy after treatment depends upon the amount of microorganisms and BOD of wastewater after treatment. It is determined during the experiment that an enzyme preparation adds energy to the system (Fig 4).

Fig 4 shows that the total amount of energy in the tank without an enzyme remains almost unchanged as the concentration of chlorides is increased. On the contrary, in the tank with an enzyme preparation the total energy level increases by 5-30\% after treatment. In both cases the data of the experiment were approximated by second-order parabolas. Bacterial spores contained in an enzyme preparation produce a renewing effect upon active sludge. The larger the amount of microorganisms, the higher the enzyme release levels; thus defence against the negative effect of chlorides is improved. As the amount of microorganisms (protozoa) in the system increases, ie the number of nutritional links is increased, the growth of biomass is reduced and more energy is consumed.

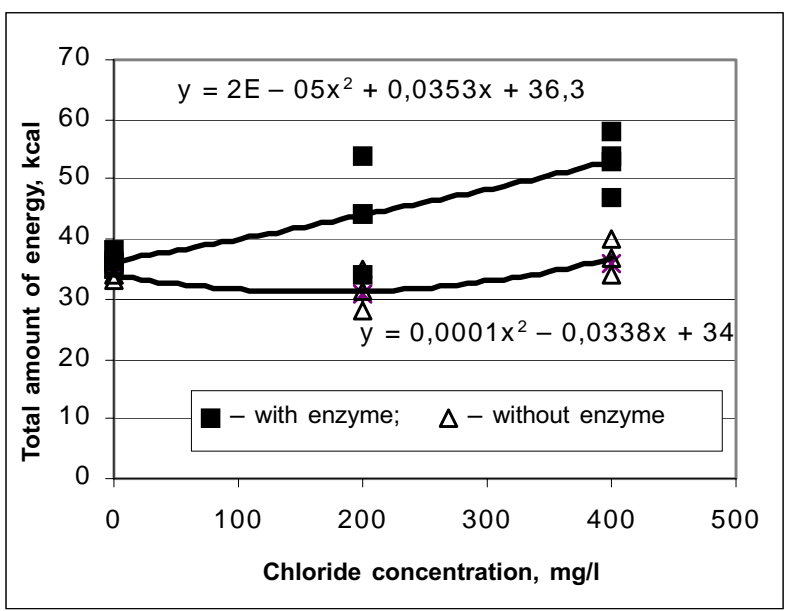

Fig 4. Dependence of the total amount of energy upon chloride concentration 


\subsection{Influence of chlorides upon biological wastewa- ter treatment}

Using $\mathrm{K}_{2} \mathrm{SO}_{4}$, the effect of sulphate ions upon the biochemical oxidation process and splitting of organic pollutants was investigated. The experiment allowed to determine the effect of $\mathrm{K}_{2} \mathrm{SO}_{4}$ on both metabolism in the active sludge system and changes in the organic matter load. Two parallel investigations were conducted: 1) $300 \mathrm{mg} / \mathrm{S} \mathrm{SO}_{4}{ }^{2-}$, 2) $700 \mathrm{mg} / 1 \mathrm{SO}_{4}{ }^{2-}$. Literature states that $\mathrm{SO}_{4}{ }^{2-}$ are characterized by the properties of acidification of the medium and inhibition of the purification process. No influence of an enzyme preparation over the efficiency of wastewater treatment was noted during the experiment (Fig 5).

Fig 5 shows that an increase in sulphate concentration in the medium results in an increase of $\mathrm{BOD}_{5}$ after treatment both in the tank with an enzyme and in the tank without an enzyme (the character of change is parabolic). One may assume that, due to their acidifying properties, sulphates damage the active centres of an enzyme and produce a destroying effect upon active sludge microorganisms.

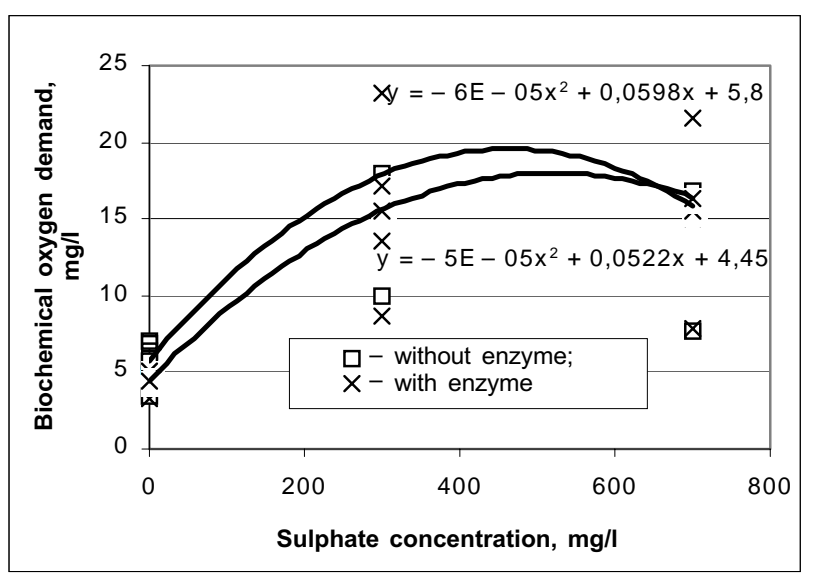

Fig 5. Dependence of biochemical oxygen demand upon sulphate concentration

Comparison of the results of experiments with $\mathrm{KCl}$ and $\mathrm{K}_{2} \mathrm{SO}_{4}$ shows that the degree of treatment (in tanks with an enzyme preparation) as determined according to $\mathrm{BOD}_{5}$ is up to $33 \%$ lower in the presence of sulphates. An assumption may be made that enzymes are affected more by sulphate ions than by chloride ions. Literature indicates that enzymes are the key factor influencing nutrition of microorganisms and biochemical treatment of wastewater at the same time. This explains a higher $\mathrm{BOD}_{5}$ value after treatment during the experiment with $\mathrm{K}_{2} \mathrm{SO}_{4}$.

Where the $\mathrm{SO}_{4}{ }^{2-}$ concentration in the tank reached $700 \mathrm{mg} / \mathrm{l}$, the active sludge was "inflated", the sludge index increased and the active sludge sedimentation properties deteriorated just as during the experiment with $\mathrm{Cl}^{-}$.

Metabolism is an essential sign of life. Each reaction of changes in substances causes an energy change in a system. An organism is an open system with a permanent equilibrium of chemical and energy exchange with the environment - metabolism. Metabolism as an entirety of complex enzyme reactions provides a basis for the functioning of a living system. Substances that get into an organism are affected by protein biocatalysts (enzymes) and non-protein parts of an active enzyme (coenzymes). The effect of enzymes and coenzymes determines the course of reactions. Under the influence of enzymes and coenzymes the initial amount of energy necessary for the processing of substrate is reduced and further transformation of substrate is regulated. The effect of enzymes helps to maintain an equilibrium between primary substances and the final products of their processing.

A very marked decrease in energy accumulation was initially observed during the $\mathrm{K}_{2} \mathrm{SO}_{4}$ experiment. One may assume that the given amount of sulphates in wastewater disarranged both metabolism of microorganisms and the activity of enzymes' active centres. However, in the course of a longer pollution process part of the microorganisms adapted to changed ambient conditions and the accumulation of energy was restored and settled to a more or less stable level. When sulphates were used as pollutants the amount of energy accumulated was by 5$40 \mathrm{kcal}$ smaller than in the case of use of chlorides.

\section{Conclusions}

1. It is found experimentally that a $400 \mathrm{mg} / \mathrm{l} \mathrm{con-}$ centration of chlorides disarranges the activity of microorganisms and at a $700 \mathrm{mg} / \mathrm{l}$ concentration active sludge is no longer suitable for biological treatment. While a high concentration of chlorides $(400 \mathrm{mg} / \mathrm{l})$ that get into a tank with wastewater reduces active sludge concentration more than twice (from $2,45 \mathrm{~g} / 1$ to $1,05 \mathrm{~g} / \mathrm{l}$ ) in five days, the use of an enzyme preparation results in a very slight change in active sludge concentration (from $2,21 \mathrm{~g} / 1$ to $1,80 \mathrm{~g} / 1)$.

2. As chloride concentrations are increased in a tank without an enzyme, the total amount of energy remains almost unchanged; in a tank with an enzyme the total amount of energy after treatment increases by 5-30\%. Bacterial spores contained in the enzyme preparation produce a renewing effect upon active sludge.

3. After additional sulphate concentrations were introduced into a biological treatment system, an enzyme preparation did not affect active sludge microorganisms and the accumulation of energy in the system. An assumption can be made that, due to their acidifying properties, sulphates damage the enzyme's active centres and produce a destroying effect upon active sludge microorganisms.

4. It is determined by calculating the accumulation of energy in an active-sludge system that an enzyme preparation increases the energy levels of the system. The amount of energy accumulated during an experiment with sulphates was by $5-40 \mathrm{kcal}$ smaller than that accumulated during an experiment with chlorides. 


\section{References}

1. Račys, V. Possibilities of small wastewater treatment facilities. In: International conference and exhibition. Small wastewater treatment facilities. Anykščiai, May 12-13, 1999, p 20-22 (in Lithuanian).

2. Eckenfelder W. W. Industrial water pollution control. New York: McGraw - Hill, 1989. 393 p.

3. Department of Environmental Protection Research methods of unified wastewater and surface water quality. Vilnius, 1994. 223 p. (in Lithuanian).

4. Water quality. Part 1. (ISO 5815:1989, modified) LAND 47-1: 2002 (in Lithuanian).

5. Water quality. Part 2. (ISO 5815:1989, modified) LAND 47-2: 2002 (in Lithuanian).

6. Aravinthan, V.; Mino, T.; Takizawa, S.; Satoh, H.; Matsuo, T. Sludge hydrolizate as a carbon source for denitrification. Water Science and Technology, Vol 43, No 1, 2001, p 191-199.

7. Skaisgirienè, A.; Lapinskienè, A. Investigation of ferment preparation influence upon the quality of biological wastewater treatment. Journal of Environmental Engineering and Landscape Management, Vol XI, No 3, 2003, p 126-132.

8. Spruogis, A.; Jaskelevičius, B. Waste and its management (Atliekos ir jų tvarkymas). Vilnius: Technika, 2000. $210 \mathrm{p}$ (in Lithuanian).

\section{CHLORIDŲ IR SULFATU ITAKA BIOLOGINIO NUOTEKU VALYMO KOKYBEI NAUDOJANT FERMENTINI PREPARATĄ}

\section{A. Skaisgirienė, P. Vaitiekūnas, V. Zabukas}

\section{S a n tra u a}

Biologinio valymo metodas dèl didelio efektyvumo, pigumo ir tinkamumo valyti ịvairias nuotekų rūšis plačiai taikomas Lietuvoje. Po ivvairių technologiniu procesų i vandens telkinius patenka įvairių mineraliniu medžiagų, kaip pavyzdžiui, chloridai ir sulfatai. Šios medžiagos biologinio valymo būdu iš nuotekų nepašalinamos. Nagrinejama, kokios chloridų ir sulfatų koncentracijos turi įtakos biologinio nuotekų valymo kokybei, tiriama fermentinio preparato itaka aktyviojo dumblo kokybei ir energijos sąnaudoms, apskaičiuota energijos pokyčiai mitybinèje mikroorganizmu grandyje biologinio valymo metu. Siekiant išanalizuoti mineralinių druskų itaką biooksidaciniams procesams buvo atlikta keletas laboratorinių tyrimų: nustatytas $\mathrm{BDS}_{5}$, aktyviojo dumblo koncentracija ir kt. Eksperimento metu nustatyta, kad $400 \mathrm{mg} / \mathrm{l}$ chloridu koncentracija sutrikdo mik- roorganizmų veiklą, o kai ji esti $700 \mathrm{mg} / \mathrm{l}$, - aktyvusis dumblas visiškai nebetinka biologiniam valymui. Taip pat buvo tiriama fermentinio preparato „Roebic“ itaka nuotekų valymo kokybei. Rezervuare, veikiančiame su fermentiniu preparatu, bendrasis energijos kiekis po valymo padidejo nuo 5 iki $30 \%$. Apskaičiavus energijos akumuliaciją aktyviojo dumblo sistemoje, nustatyta, kad fermentinis preparatas suteikia sistemai papildomos energijos.

Raktažodžiai: aktyvusis dumblas, fermentai, biologinis nuoteku valymas, sulfatai, chloridai.

\section{ВЛИЯНИЕ ХЛОРИДОВ И СУЛЬФАТОВ НА КАЧЕСТВО БИОЛОГИЧЕСКОЙ ОЧИСТКИ СТОЧНЫХ ВОД ПРИ ИСПОЛЬЗОВАНИИ ФЕРМЕНТНЫХ ПРЕПАРАТОВ}

\section{А. Скайсгирене, П. Вайтекунас, В. Забукас}

P е 3 ю $\mathrm{M} \mathrm{e}$

В Литве широко применяется высокоэффективный и дешевый метод биологической очистки сточных вод. В результате технологических процессов в водные источники попадают такие минеральные вещества, как хлориды и сульфаты. Эти вещества методом биологической очистки из воды не удаляются. В настоящей работе исследованы концентрации хлоридов и сульфатов, оказывающие влияние на качество биологической очистки сточных вод, проанализировано влияние ферментного препарата на качество активного ила и энергетическую потребность, а также рассчитаны энергетические изменения в трофической цепи питания микроорганизмов. Для определения влияния минеральных солей на биологические процессы были проведены лабораторные исследования: определен БПК, концентрация активного ила и др. В результате экспериментов было установлено, что концентрация хлоридов в 400 мг/л поражает работу микроорганизмов, а при концентрации в 700 мг/л активный ил становится абсолютно непригодным для биологической очистки. Также исследовалось влияние ферментного препарата „Roebic“ на качество очистки. Общее количество энергии в резервуаре с ферментным препаратом после очистки увеличилось с 5 до $30 \%$. Рассчитав аккумуляцию энергии в системе активного ила, удалось установить, что ферментный препарат повышает энергию биосистемы.

Ключевые слова: активный ил, ферменты, биологическая очистка сточных вод, сульфаты, хлориды. 